\title{
VERBAL POLITENESS AS A REGULATOR OF VERBAL INTERACTIONS
}

\author{
Shamahmudova Aziza Furkatovna (PhD) \\ Djalilova Sarvaroy Mekhrojevna
}

Samarkand State institute of foreign languages

$(\mathrm{PhD})$ Department of Spanish and Italian languages

\begin{abstract}
This article deals with politeness theory which is of great importance in interpersonal communication. Politeness is characterized from the pragmalinguistics point of view, examples are given to demonstrate the presence and absence of politeness in the Hispanic discourse. Suggestions are provided on how to teach students politeness strategies in Spanish as a foreign language class. The necessity of correlating the categories of politeness with grammatical categories and context has been substantiated. This technique will allow foreign students to learn the rules of language behavior that exist among the Hispanic population.
\end{abstract}

Keywords

Pragmalinguistics, politeness theory, speech acts, verbal strategy, verbal and non-verbal communication, communicative functions, positive and negative image.

Article Received: 18 October 2020, Revised: 3 November 2020, Accepted: 24 December 2020

An extensive study was performed and postulated that the ways of addressing a person depends not only on our communicative intentions, but also on other ethnosociopragmatic factors, such as the degree of trust, age differences, hierarchy, etc. In other words, there are social relations between the speaker and the listener, which are organized around two main axes (Kerbrat-Orecchioni, 1992): a horizontal axis, determined by the level of prior knowledge, trust and intimacy, and allowing build relationships in terms of equality, and a vertical axis, establishing hierarchical differences based on age, status, acquired knowledge and etc.

Thus, in order to explain how social relationships occur in communicative acts, it will be appropriate to reveal two other fundamental terms.

The first is the image of Goffman (1967) presents communicative activity as a theatrical play in which the participants play a role determined as the action develops. The image is not what we really are, but how we position ourselves and what we strive to demonstrate to others. In this regard, a number of rituals are developing that try not to harm the image of the participants, or to restore it and compensate if the communication went in a negative way.

The next key concept is territory. Initially, this concept is associated with the distribution of territory, but it is easily "charged" with psychological and symbolic meaning. That is, it includes some aspects that the social object considers purely personal, and if you touch them, then a conflict can arise. There are some topics that we consider very personal, and we prefer not to discuss them, as this would involve interference with our innermost feelings, inner world.

These two concepts have become key in the theoretical description of verbal politeness, which has had a great resonance in recent decades: the work of P. Brown and S. Levinson (1987). According to these authors, each member of society has his own public image, which he creates for himself. This image is formed by the totality of desires that everyone has, and represents two sides that complement each other:

- negative side: desire for freedom of action, to be free from coercion, to control one's territory;

- the positive side: the desire to be appreciated and accepted by others, so that other people share his desires. 
As for verbal communication, it is argued that there are speech acts characterized precisely by placing the public image of participants in danger in any of its sides. Thus, there are:

- acts that threaten the negative image of those who implement them: promises, agreements, since they restrict the freedom of human actions;

- acts that threaten the positive image of those who carry them out: recognition, self-criticism, since they are self-deprecating and endanger the social image of a person;

- acts that threaten the negative image of another: incentive or directive acts, since they invade the territory of another person and restrict the freedom of his actions;

- acts that threaten the positive image of another: insults, ridicule, reproaches, denials, since they affect a person's desire to be appreciated and recognized by others.

The potential threat of a speech act is formed from the following variables (Brown, Levinson, 1987: 76): social distance between interlocutors (horizontal axis), relative power between them (vertical axis) and the level of coercion in speech act, that is, cost/benefit, which its implementation brings to the interlocutors. An increase in any of the above should result in a greater expression of politeness. For example, in terms of the last variable, asking someone to hand over a salt shaker and asking them to borrow a large amount of money is not the same thing.

Politeness is involved as a corrective measure to maintain social balance and avoid conflict. Depending on a favorable public image, we are talking about positive politeness, focused on maintaining a positive image of the interlocutor (interest in his words, the manifestation of empathy, trust), and negative politeness, supporting his negative image and trying to avoid: a person seeks not to impose anything, not challenge the desires of another, that is, soften the situation and not invade the interlocutor's territory.

The most interesting thing is that a number of strategies are established here which can be expressed verbally, in different forms. Each strategy implies different ways of perceiving social relations with the interlocutor. Five types are offered, ranked from lowest to highest threat risk:

1. Open and direct strategies that do not take into account the public image of the other (in situations of familiarity, clearly expressed hierarchy, exceptional urgency): Ponte a fregar inmediatamentelo splatos;

2. Open strategies focused on a positive image: Anda, cariño, porfa, ¿friegas tú los platos y yo recojo la cocina?;

3. Open strategies oriented in a negative way: Juan, sino estás ocupado, ¿podrías fregar los platos? es que no hay ninguno limpio;

4. "Disguised" strategies: this implies an indirect use of the language. Some type of hint is proposed that allows the interlocutor to draw a conclusion about the true intention of the speaker: El fregadero está lleno de cacharros y ya no hay platos para la cena;

5. Avoiding the implementation of the act of threat.

Brown and Levinson's work was one of the most influential, yet it was criticized frequently nonetheless. Especially, she was reproached for some kind of ethnocentrism, and in particular, that their model reflects the politeness prevailing in Western culture of the Anglo-Saxon type. However, this criticism is completely unjustified, since Brown and Levinson constantly refer to the relevant data of non-European languages and cultures and also make it clear that only the general principles of the model are universal, while their application varies in different cultures (1987: 283). Thus, the concept of a public image is universal, as is the need to preserve it in relations with others, but still, the specific factors that determine it as a desired image vary from culture to culture.

More justified is the reproach that they presented a very pessimistic and even paranoid vision of social relations. It turns out that you cannot take a single step without threatening your own and someone else's public image. These authors place too much importance on negative 
politeness. Within the framework of such an attitude, Kerbrat-Orechoni (2004: 43-44) emphasizes that along with acts of threat, there are other acts that pursue opposite goals: to increase the importance of the public image of the interlocutor. They are usually inherently polite and strengthen social relationships: compliment, praise, gratitude, expressions of good wishes, congratulations, etc.

We believe that materials used to demonstrate certain purposes of language can be used to induce a student to reflect on the importance of verbal politeness. For example, some comics "Mafalda" by the artist Kino show how concepts such as social image, territory, contextual adaptation can be explained in a synthetic, inductive and humorous form, without delving into theory. Thus, the following comic shows how Guilier, not understanding the importance of social constraints, answers her mother's question sincerely and clearly, but inappropriately. Here is a clear example of how sometimes there is a clash between the norms of the principle of cooperation (Grice 1975), according to which clear and transparent information should be conveyed, and the norms of the principle of courtesy, when trying to maintain good social relations.

On the other hand, the text of Rosa Montero ("Mentiras, mentirazas y mentirijillas" - "Lies, small and large") allows us to demonstrate the opposite situation: how this "good" lie helps to maintain social connection, despite the fact that it contradicts the principle of conversation, which requires us to be sincere:

"Y es que la mentira, cierta mentira bien intencionada y educada, es el necesario lubricante social que hace que los cojinetes de las relaciones funcionen como es debido. Detesto a esos individuos que van de sinceros por la vida, que alardean de su autenticidad sin tapujos ni bridas y que, en realidad, sólo son unos brutos y unos groseros, porque además para lo único para lo que suelen ser sinceros es para los comentarios desagradables "(El País Semanal, 15 de agosto de 2004) - The point is that well-intentioned lies serve as the necessary social "lubricant" to enable all the " bearings "of the relationship to function properly. I hate those people who go through life with sincerity, flaunt their unbridled truthfulness in plain terms, but in fact, they are just rude, because they are usually sincere only for unpleasant comments.

Obviously, it is almost inevitable to introduce the concept of "politeness" without covering certain grammatical topics (personal pronouns, imperative mood, conditional mood, etc.). Politeness is indeed associated with certain grammatical categories, and affects most of the levels of the language. However, in senior years, it might be helpful to look at politeness more broadly and globally so that through simple and clear examples help students think about what verbal politeness is and about fundamental issues such as:

- in any communicative event two alternatives appear before us: to be polite or to be impolite;

- politeness should not be confused with formal language or courtesy;

- we can be polite in different ways, depending on the type of public image we create;

- for the most part there are two main strategies: one is focused on convergence, empathy (positive politeness), and the other - to maintain distance, non-interference in the space of another (negative politeness);

As far as verbal expressions of politeness are concerned, here we are not talking about offering a more or less broad repertoire of polite formulas. It would be more appropriate to bring the student closer to a number of more general strategies that are not exclusively inherent in politeness, but have much in common with it: we mean verbal operations of softening and intensification (AntonioBriz 2004a: 229-231; 2002: 71-76, 110117 ). The first is the "strategic linguistic operation of minimizing the stated point of view" (2004a: 230). It is about softening, depriving illocutionary power, hiding true intent in order to avoid possible responsibility. Therefore softening is typical of softening or negative politeness. As compensation, the opposite is more appropriate in some contexts: intensification. Here the speaker 
gives more strength to his actions, thoughts, he manifests himself more directly and temperamentally. As far as politeness is concerned, there is an evaluative or positive politeness that is typical of close relationships, trust and lack of threat. Both of these operations are verbally expressed in different ways (vocabulary, morphology, stereotypical phrases and formulas, phonetics, paralinguistics, etc.) and exercises should be developed where students, based on specific contexts, will use different techniques to make a choice in benefit of one or another type of politeness:

- La paella te ha quedado estupenda/La paella te ha quedado BUENA, BUENA, ¡REQUETEBUENA! (+ reinforcement, + politeness);

- ¡So inútil! ¡Más que inútil! Todo el día metiendo la pata (+ reinforcement, politeness)/Has cometido un error (neutral)/Sólo hay un pequeño error sin importancia (+ softening, + politeness)

In a different state of affairs, we are convinced that familiarity with the strategies of politeness should be carried out from a perspective that takes into account the basic mechanisms of the functioning of spontaneous conversation. It is intended to address issues such as the following:

Conversation in turn: the conversation develops through an unconditioned alternation of queues. Usually, there are no problems with changing the queue. There are so-called "places of the corresponding transition", which, with the help of verbal signs or gestures, indicate the possibility of the beginning of a new queue. It should be recognized that this mechanism of alternation is usually not considered in textbooks, perhaps because it is perceived as something spontaneous and easy to learn, although, in fact, it presupposes possession of a wide variety of discursive features, as well as certain sociocultural norms of interaction. Not knowing them can lead to problems, just like this Japanese girl:

- When Suzuik arrived in Spain, she wanted to turn to talk, and for a long time could not put in a word in a general conversation. One day her friends said to her: "Why do you never talk?" She replied, "Because you never let me." And then they explained to her that here the turn to speak is not inferior, but it is necessary to "conquer" her, "pushing others aside." She laughed and said, "When I got here, the groups of girls talking to me looked like cockfighting." (I. Monsó, País Semanal, 28.04.2002, p. 168).

It is clear that Suzuki did not recognize boundaries that indicated the possibility of changing lines, so her behavior, from the Spanish point of view, was pragmatically inadequate. This joke also demonstrates to us another important fact: sometimes there are overlaps, interruptions, instant assignments in the alternation of a queue. The motives for her appearance may be different. However, we now want to emphasize that not always changing the queue implies a gap and not always interrupting each other (Briz 2003: 69-74; CesteroMancera 2005: 34-39). On the contrary, it is sometimes seen as a sign of cooperation, assistance, interest and attention. Therefore, in our opinion, one should abandon the stereotypes that are very widespread among foreign students, such as, for example, the aspect cited by A. Briz: "In Spain, before a person finishes a phrase, another person starts to speak. Often they interrupt the speech of another, and this is normal for them, but it seems to me bad manners "(2002: 10). Obviously, all this has nothing to do with bad parenting, but simply different ways of verbal communication. Spaniards, in spontaneous conversations, openly lean towards positive politeness, involving intense and direct involvement, which fosters this type of interruption and overlap of phatic and cooperative functions.

An exchange is a structural unit of conversation, consisting of two successive queues produced by two speakers. The type of cooperative exchange "adjacent pair" is very important. Adjacent pairs, typical for a conversation, are question/answer, invite/acceptrefuse, offer/accept-refuse. A special mechanism in the functioning of adjacent pairs is the concept of priority or preference (Levinson 1989: 294), 
based on the reflection that the second part of the adjacent pair may have in the social image of the interlocutors. Thus, there are second priority parts that favor social relationships (for example, accepting an invitation) and second non-priority parts that can compromise the relationship (for example, refusing an invitation). This proves that the concept of priority is closely related to the expression of verbal politeness. All this has a structural and formal reflection, since the second preferred parts are not labeled, that is, they contain simple and direct answers, while the nonpreferred ones have structural marking through the appearance of delays, omissions, excuses, explanations, etc. (Levinson 1989: 294-295 ). The importance of these factors in a second language learning environment is critical, as priority or nonpriority varies across cultures. Thus, our students should be taught the second priority parts of the most common adjacent pairs. In addition, if students are required to produce a second nonpriority queue, they should be aware to use mitigation strategies that will mitigate the potential conflict when using the non-priority queue. The result will be linguistically more complex and elaborate:

-A: Javier, pasa mañana por casa, te quedas a comer y hablamos más tranquilamente.

- $B$ : La verdad, me encantaría, pero me viene mal. He quedado ya con Susana para ir a comprar un nuevo ordenador. Si quieres, nos vemos la próxima semana.

Interactive development of communication functions. Usually, when the study of speech acts is planned, examples are offered consisting of one utterance or at most, an exchange of two utterances (a typical adjacent pair). For a starting point, this may be fine, but if the teacher wants students to act less rudely and more attentively to the social image of the interlocutor, he should familiarize them with more complex interaction strategies. The results of this approach may vary. First of all, since we are the bearers of a particular language and culture, we are accustomed to certain norms of behavior formed by a conditioned sequence of actions, and we expect everyone else to respect these norms. If this is not the case, then the result is pragmatically abnormal, and even clearly impolite. For example, in Spanish culture (Miquel, 1997), praise is usually expressed in the following scenario: A praises B, $\mathrm{B}$ invalidates the praise, $\mathrm{A}$ insists, $\mathrm{B}$ thanks for the praise and makes some comment; and when something is proposed in a formal context, they usually act like this: A offers something, B does not accept the offer, A insists, B finally accepts. However, these norms of behavior change in other cultural contexts and ignorance of them can affect the social image of the interlocutors.

Moving away from these more stereotypical situations, it should be understood that various speech acts are usually a complex structure, consisting of several parts (Escandell 2004: 188189). For example:

"Juan, ahora que estás de vacaciones y tienes tiempo, ¿por qué no te animas a sacar el carnet de conducir? Tevendría muy bien de cara a encontrar un trabajo en el futuro "

In this example we can highlight the core (the minimum content that can be expressed in a speech act, in this case an interrogative sentence), an appeal (a call to attract the attention of the interlocutor) and various auxiliary parts that mitigate the impact of the speech act (explanations and justifications). Therefore, it is necessary to navigate in the perspective of sequences, discourse, both monological and dialogical, and promote the emergence of macro acts or macro functions, that is, sequences of pragmatically interrelated statements that correspond to a general strategy. In a macro act, one can distinguish between a core or central act, and a number of optional acts that support the former, and usually correspond to various strategies of politeness. The emergence of such acts of support turns out to be necessary when our communicative goals conflict with the goals of the interlocutor and can affect his social image:

Perdone, ya sé que no se pueden sacar los libros más de tres días, y que las normas son las normas, pero necesitaría algo más de tiempo para terminar un trabajo sin el que no puedo aprobar 
la asignatura. De verdad, me haría un auténtico favor.

Usually, during the introduction of a certain communicative function in the audience, this is limited to more conventional formulas and general use. However, at least students with a high level of language proficiency should be made aware that there are many different alternatives for expressing the same speech act, and they correspond to different contexts and strategies of politeness.

The method of linguistic demonstration of a speech act depends not only on the speaker's intention, but also on the relationship between the interlocutors (level of trust, hierarchy, etc.), and the impact that the performance of the speech act can have on these relationships (Escandell 2004: 191). Such effects can be measured using a cost/benefit scale (Leech 1983), which allows us to distinguish between two broad categories of speech acts:

- polite: favorable to the interlocutor and suggesting cost or effort for the speaker. They help strengthen social relationships: congratulations, greetings, gratitude, apologies, invitations, promises ...

- not polite: they assume some kind of cost for the listener, and, on the contrary, a certain benefit for the speaker. A paradigmatic example is incentive acts that do not allow objections: requests, entreaties, orders ...

The linguistic impact of these speech acts plays an important role, and student should be able to distinguish them well. Indeed, typical polite acts tend to be expressed directly, without compensation strategies. In addition, the possibility of intensification and expressive effort is perceived well in them. On the contrary, typical impolite acts require the use of various strategies aimed at compensating for their impoliteness if the speaker seeks to maintain some kind of social balance. In this regard, mitigation techniques can be very helpful.

As an example of the latter, one can cite motivating speech acts that do not require objections. With their help the speaker wants the listener to take a certain action for the benefit of the first. This happens in case of requests. For example, we want our interlocutor to close the door of the room in which we are. We are faced with many different alternatives to express this intention. We can use a direct formula containing an imperative verb: "Cierra la puerta", which can be softened with por favor: "Por favor, Juan, cierra la puerta" or strengthened with interjections: "Cierra la puerta, jcoño!" You can also use the verbs of realization, denoting the performed speech act: "Te ruego que cierres la puerta" (without modification), "Le debo pedir que cierre la puerta" (with modification). They are also very cost-effective, as formulas for expressing negative politeness, these are so-called conditional indirect acts: "Puedes cerrar la puerta?, ¿Quieres cerrar la puerta?” The introduction of the conditional mood as a result of the expressed metaphorical distancing adds even more politeness: "¿Podrías cerrar la puerta? ¿Querrías cerrar la puerta?”. There is no need to mention the ability or desire of the listener for the interrogative sentence to function as a request: "¿Cierras la puerta?" This formula is perceived as polite, without any frills. On the other hand, the pseudo-inclusive mention of the first person (Haverkate 1994: 183-184) can also serve to express mutual courtesy: ¿Cerramos la puerta? Finally, there are many alternative expressions that can be characterized as explicit, since the exact meaning of a request is deductively determined only in very specific contexts. The politeness level is also different: ¡Eh! ;La puerta !, Te has dejado la puerta abierta, ¿Has cerrado la puerta? Hace frío aquí, ¿no? ¿Qué hace frío, eh !, Se va a escapar el gato ...

From a didactic point of view, it is clear that the student, of course, does not need to memorize long lists of various alternative techniques for expressing the same communicative function. At any time, the contexts of use in which these linguistic procedures fit and the various associated levels of politeness should be taken into account. Teaching must be fully contextualized, as otherwise there is a danger that the student will 
use a certain type of statement in the wrong context. The importance of contextualization lies in the fact that even the most conventional formulas of expression of politeness (¿Puedes cerrar la puerta ?, ¿Te importaría cerrar la puerta?) With the appropriate intonation can add contextual shades of impoliteness, expressions of irritation, impatience, irony ... Therefore, it is very important understand the differences between codified and interpreted politeness (Briz 2004b).

The expression of speech acts has a different perspective: the same linguistic indicator can be associated with different communicative functions. Therefore, one should avoid identifying it with a specific speech act. An example is the imperative mood. In basic grammatical descriptions, it is usually identified with an expression of command, and tends to be seen as impolite. However, in reality, everything is much more complicated. The imperative mood can be used to express initially polite acts and invitations:

Sírve te un poco más de sopa, está muy buena, good wishes: Pasadlo bien, Mejórate; granting permission: - ¿Puedo entrar? - Entre, entre. In some cases, it takes on a connotation of convention:

Sigue mis consejos y no te arrepentirás. Suspende y te acordarás de quién soy yo.

Within the framework of motivation, the imperative mood is used to express supplications, requests, orders, advice, suggestions, etc. Therefore, it should be made clear to the students that the imperative mood is not polite or impolite in itself. Even in non-objectionable speech acts (at some cost to the listener), the use of the imperative mood is not always impolite (Haverkate 1994: 165-166): in familiarity contexts: Cariño, tráe me la camisa que está enlapercha; in everyday exchanges of clearly defined statements: Camarero, póngame un café con leche; or when asked for some low-effort action. Thus, in front of this richness and variety in the use of the imperative mood the explanations in the textbooks are generally very restrained, and practically do not take into account the various contexts of its use.
Thus, in the face of this richness and variety in the use of the imperative mood, the explanations in the textbooks are generally very restrained, and practically do not take into account the various contexts of its use.

We would like to coclude our reflections by emphasizing the need to include an intercultural perspective in the study of politeness. To do this, we will use the story of a student from the United States, where she shares her impressions of her stay in Spain during the entire course.

Her first impression concerns the oral communication of the Spaniards:

"...family members usually have their own specific opinions on different topics, but arguments and disputes are common. I often think that all relatives are annoyed because they constantly speak in a raised voice, but this is not considered a sign of disrespect or impolite ..."

Obviously, this girl realized that the way of communication in Spanish family differs from her country in terms of paralinguistic means (tone, rhythm, intensity) as a way of expressing opinions. She emphasizes that in Spain there is a tolerance for expressing opinions, even when they differ from their own, which promotes liveliness of conversation and stimulates the exchange of opinions (Bravo 1999: 169). In contrast, in other cultural spheres, such as in Uzbek, a desire for cohesion prevails in order to avoid conflicts and to agree with the interlocutor (Bravo 1999: 172).

Another impression relates to the way of expressing speech acts as advice, recommendations, etc. If in her country it would be normal to use more indirect and softening techniques, then here in Spain, the woman with whom she was visiting used the imperative mood for elevated, in her opinion, tones:

- If you are studying in Leon and living with a Spanish family, I assure you that you do not need to be afraid and think that your "Spanish mom" hates you. She will speak very loudly, often commanding: "Dress warmly!", "Eat!", "Never dress like that again!", But this is a manner of giving advice and trying to help you, this is not something unpleasant. 
Of course, in a family context, when it comes to actions that favor the listener, the imperative mood cannot be seen from a Spanish perspective as a sign of impoliteness, although the student's first impression was different.

Certainly, thanks to the long process of being in the linguistic environment, this girl managed to realize that some moments, from the point of view of cultural norms in her country, which can be considered an example of conflict, irritation, aggressiveness or impoliteness, are quite normal from a Spanish perspective. If this girl continued to adhere to the norms of behavior of her culture, she would have made the mistake of pragmatic activity, and her opinion of the Spaniards would be filled with prejudice. Therefore, teaching a foreign language should be aimed at making students aware of these differences, and when using a new language, pay attention to the norms of behavior of the corresponding culture.

Thus, it seems clear to us that although the concept of politeness is universal, there are still differences in the way it is perceived (depending on the prevailing type of social image), and in the verbal strategies used to express it. If one do not attach importance to this aspect in teaching a foreign language, this can cause pragmatic errors of the pragmalinguistic type, that is, associated with the use of verbal formulas to express a certain speech act, or sociopragmatic type, namely, relating to the way of perceiving social relations between interlocutors and adequate behavior (Blum-Kulka 1996; Escandell 1996).

We insist that language learning should pay attention to these differences and possible pragmatic errors, especially when there is a risk of cultural misunderstanding or evaluating other unfamiliar factors with the help of prejudices. For this, the comunicants should be offered clear, pragmatic detailed information detailing the contexts of using the most important speech acts and the means of expression most appropriate to these contexts.

\section{References}

[1] Brown R. Levinson S. Universals in Language Usage: Politeness Phenomena // Questions and Politeness: Strategies in Social Interaction. - Cambridge Univ. Press. - 1987. - P. 56-289.

[2] Blum-Kulka S. Playing it safe: The role of conventionality in indirectness.In: BlumKulka, House y Kasper (comps.), Crosscultural pragmatics: Requests and apologies. - Norwood, NJ: Ablex, 2000. P. 155-177.

[3] Bravo, Diana: «¿Imagen "positiva" vs. Imagen "negativa"?: pragmática sociocultural y componentes de face», en Oralia, 2,1999,155-184.

[4] Briz Gómez Antonio. La estrategia atenuadora en la conversación cotidiana española, en Diana Bravo (ed.), La perspectiva no etnocentrista de la cortesía: identidad sociocultural de las comunidades hispanohablantes, Actas del 1er Coloquio del Programa EDICE. www.edice.org, 2003.

[5] Cestero M., Ana M.a: Conversación y enseñanza de lenguas extranjeras, Madrid: Arco Libros, 2005. - 248 p.

[6] Escandell V., María V. Aportaciones de la pragmática. En: Sánchez L.J.,Santos G. I. (eds.), Vademécum para la formación de profesores. Enseñar español como segunda lengua (L2)/lengua extranjera (LE). Madrid: SGEL, 2004. - 345 p.

[7] Goffman Erving: Interaction ritual: Essays onface toface behaviour, Nueva York: Garden City, 1967.

[8] Grice Herbert Paul: «Logic and conversation», en Syntax and semantics 3. Speech acts, P. Colé y J. L. Morgan (eds.), Nueva York: Academic Press, 41-58.

[9] Haverkate H. La cortesía verbal. Estudio pragmalinguiístico. - Madrid: Gredos, 1994. $-245 \mathrm{p}$.

[10] Kerbrat O. Les interactions verbales, II, París : Armand Colin, 1992. - 145 p.

[11] Leech G. Principles of pragmatics. - L. - 
N.Y.: Longman.-1983.- 250 p.

[12] Levinson, Stephen C: Pragmática, Barcelona: Teide, 1989.

[13] Miquel, Lourdes: «Lengua y cultura desde la perspectiva pragmática: algunos ejemplos aplicados al español», en Frecuencia-L, 5, 1997, 3-14.

[14] Portoles, José: Pragmática para hispanistas, Madrid: Síntesis, 2004. - 107 p.

[15] Tuson, Amparo: Análisis de la conversación, Barcelona: Ariel, 1997. $97 \mathrm{p}$. 